\title{
ASSESSMENT OF THE PROSPECTS FOR THE DEVELOPMENT OF TRADE RELATIONS OF THE BALTIC COUNTRIES AND SOUTHEAST ASIA
}

\author{
Inna Stecenko'
}

\begin{abstract}
In the presented article, the author conducts research of export - import operations between the Baltic countries and the countries of Southeast Asia from 2016 to 2018, since the goal for the EU countries is to deepen economic relations between the countries of Asia; however, there has been no serious analysis of the potential of trade relations between the regions. Based on empirical studies, the countries of Southeast Asia are identified by the volume of export - import, which is significant in the economy of states. It has been revealed that the Baltic countries import more products from the countries of Southeast Asia; however, the increase in the competitiveness of the industries is related to the volume of exports as well. To strengthen trade relations between the regions of Asia and the EU, the implementation of the adopted UN resolution on the Transformation of our world: The 2030 Agenda for Sustainable Development, the national programs on the development of the economy of countries, the author identified the potential for exports of the Baltic countries to the corresponding countries of Southeast Asia. The analysis of the number of tourists from the countries of Southeast Asia is carried out, the results of which show the potential for the growth of this industry and the strengthening of trade relations between countries. Taking into account the volume of trade between the Baltic regions and the countries of Southeast Asia, the role of small and medium-sized enterprises is shown. The author carries out the analysis of the conditions for the registration of SMEs in the Baltic countries, the number of employees in SMEs.
\end{abstract}

Key words: the Baltic countries, countries of Southeast Asia, export-import operations, tourism, small and medium - sized enterprises.

JEL Classification: F10, F20, M29

\section{Introduction}

The modern development of economic and trade relations between countries is based on a number of important documents, thus the need to strengthen the relationship between Asian and European countries was identified by Resolution adopted by the General Assembly in September 2015. At the General Assembly, the United Nations adopted one of the most important documents of the United Nations Summit: the transformation of our world: The 2030 Agenda for Sustainable Development. Seventeen goals were developed in this document in the field of sustainable development of the world and 169 tasks were declared as the future development program of the countries of the world. The new goals and objectives entered into force on January 1, 2016. The countries will be guided by them for making decisions over the next 15 years in implementing the economic policy. Within the framework of the research presented on the development of export-import operations of the
Baltic countries and the countries of Southeast Asia, we rely on the implementation of the eighth and ninth goals of this document. Thus, goal 8 is formulated as "Promote inclusive and sustainable economic growth, employment and decent work for all" (The Sustainable Development Goals). Undoubtedly, trade has been and is the basis for the growth of welfare and prosperity of states for many millennia, along with that, under the conditions of industrialization of states and the support of innovative activity, an additional impetus is being created to increase trade operations between states.

The goal of the research presented is to find directions for strengthening trade relations between the Baltic countries and Southeast Asia. To achieve this goal, the author performs the following tasks: the analysis of the export-import operations of the Baltic countries and Southeast Asia is carried out, the volume of operations in the total export-import is calculated; the leaders of the Southeast Asian countries in trade with the Baltic countries in both export and import are identified, the

\footnotetext{
Corresponding author:

${ }^{1}$ Baltic International Academy, Latvia.

E-mail: i.stecenko@yahoo.com

ORCID: http://orcid.org/0000-0002-0277-286X
} 
development of related industries of economy, tourism to the Baltic countries, is shown and the analysis of the registration of SMEs in the Baltic countries is registered.

The research methodology is based on the use of quantitative and qualitative research methods: a content analysis of literary resources on the topic research, comparison and evaluation of the results obtained in them; methods of statistical analysis used to assess the dynamics of absolute indicators, identifications of their relationships; a graphical method that ensures the visibility of the economic relations of the participants of trade operations analyzed by the states.

\section{Previous research review}

Almost two and a half centuries have passed since the time of A. Smith and his theory of absolute advantage, as before, the topic of building trade relations is relevant for states.The theory of comparative advantages of D. Ricardo and D. SMill., the Heckscher-Ohlin theorem, Leontief paradox,the theory of product's life cycle, which was put forward and substantiated by R. Verna, C. Kindleberger and L. Wales, M. Porter's theory, Rybchinsky's theorem, as well as theory of Samuelson and Stolper, explained and clarified the laws of trade between countries. In early 1980s, P. Krugman, K. Lancaster and several other economists suggested an alternative to the classical explanation of international trade, based on the so-called economies of scale. Further, an analysis of the factors of the international division of labor was complemented by the neo-technological concept of I. B. Kreivis. According to Kreivis, each country imports goods that it is either not able to produce on its own or can produce in limited quantities whose supply is elastic, while at the same time exports goods with highly elastic and superior local production requirements. As a result, the country's foreign trade is determined by the comparative level of elasticity of the national and foreign supply of goods, as well as by the higher rates of technological progress in export sectors.

\section{Methodology and preliminary analysis}

Analysis of export-import operations of the Baltic countries and Southeast Asia.

Thus, this research is aimed at analyzing and assessing the potential for the development of trade operations between the Baltic countries and the countries of Southeast Asia. It should be noted that support of trade relations between the European countries and Southeast Asian countries is carried out at the level of both the EU and ASEAN ministries. On March 3, 2016, the ASEAN Economic Ministers (AEM) and the EU Trade Commissioner held their Fourteenth Consultations in Chiang Mai, Thailand. On May 2015,the High Representative of the European Union for Foreign Affairs and Security Policy and the European Commission adopted the Joint Communication: "The EU and ASEAN: a partnership with a strategic purpose". The Joint Communication puts forward concrete ideas for taking EU-ASEAN (The Association of Southeast Asian Nations) relations to the next level by providing a more coherent framework for sectoral cooperation. Let us consider how export-import operations between the EU and ASEAN have been developing in 2016-2018 (Figure 1).

As you can see from the data presented in the diagram, in general, imports from ASEAN countries exceed exports, with the difference from $29.1 \%$ in 2016 to $31 \%$ in 2018 . A positive trend should be noted by the linear growth of both imports and the EU exports to ASEAN countries.

Thus, the object of our research is the Baltic countries. Let us carry out the analysis of the most important economic indicators of states (table 1).

As you can see from the table represented, the largest population of the Baltic countries is 2.81 million in Lithuania, 1.93 million in Latvia and 1.32 million people in Estonia. Countries are characterized by low population density: about 30 people per $\mathrm{km}^{2}$ in Estonia and Latvia, but 43 people per $\mathrm{km}$ in Lithuania. About 19000 EUR GDP per capita in Estonia, 16 793.25 EUR

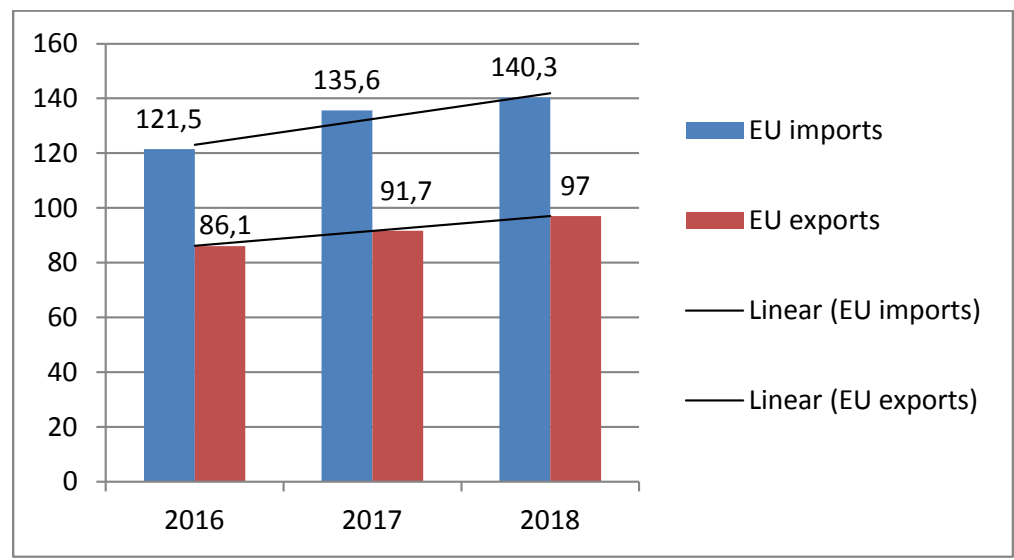

Figure 1. EU-ASEAN (The Association of Southeast Asian Nations): trade in goods, bln EUR in 2016-2018, calculated by the author 
Table 1

Analysis of the economic indicators of the Baltic countries, developed by the author (Latvijas Centrālās statistikas pārvalde; The Lithuanian Department of Statistics (Statistics Lithuania); The Statistics Estonia)

\begin{tabular}{|l|c|c|c|}
\hline \multicolumn{1}{|c|}{ Indicators } & Estonia & Latvia & Lithuania \\
\hline Number of inhabitants, $\mathrm{mln} 2018$ & 1.32 & 1.93 & 2.81 \\
\hline Number of inhabitants, people $/ \mathrm{km}^{2}$ & 28 & 29.95 & 43 \\
\hline GDP per capita, EUR, 2018 & 18977.39 & 15553.33 & 16793.25 \\
\hline Net salary, EUR, 2018 & 1325 & 1004 & 921 \\
\hline
\end{tabular}

Source: own study based on data of the Nationals Statistics data bases

in Lithuania and 15553.33 EUR in Latvia. Taking into account the territorial and cultural proximity, historical similarity, the economies of states are identical to a great extent. As it is indicated in the EU report, "three countries - one economy". However, to achieve the stated goal, let us consider how export-import operations with the countries of Southeast Asia are distributed across the Baltic countries.

To carry out an analysis, we selected those countries of Southeast Asia with which the Baltic countries have any significant trade operations. Thus, an insignificant share or practically no trading operations of the Baltic countries with Indonesia, Malaysia, Brunei and Vietnam.

\section{Results}

Thus, let us carry out an analysis of the export-import operations of the Baltic countries, which is represented in table 2.

Thus, for the studied year 2017, the share of Asian countries in the total volume of trade operations of the Baltic States is a significant part (Figure 2).

On the chart calculated by the author, it is clearly seen that the largest volume of imports from Southeast Asian countries in Estonia is $2416.37 \mathrm{mln}$ USD, which in nominal terms is equal to the sum of imports from Southeast Asian countries in Latvia and Lithuania. The volume of imports from Southeast Asian countries to Estonia is $16.6 \%$ of the total imports to the country, $3.77 \%$ of the total operations in Latvia in 2017 and 3.7\% in Lithuania.

It should be noted that the role of the countries examined in trade operations not only in the Baltic countries, but also in the European Union as a whole is great, thus, according to the European Commission: China is now the EU's second largest trading partner behind the United States and the EU is China is the largest trading partner; the EU exports of services to South Korea increased by $82 \%$, compared to $66 \%$ for the EU imports from the country from 2010 to 2017.

The EU had a 5.6 bln EUR trade in services surplus with South Korea in 2017. Singapore is the EU's 14th largest trade in goods partner and the EU's largest trading partner in the Association of Southeast Asian Nations (ASEAN). The EU is Taiwan's fourth trade partner after China, the USA and Japan. In 2018, Taiwan was the EU's seventh largest trading partner in Asia. The EU exports to Taiwan of semi-finished products, machinery and transport equipment confirm the EU's position as an important industrial supplier for Taiwan's industry. Japan is the EU's second biggest trading partner in Asia after China. Together the EU and Japan account for about a quarter of the world's GDP. Hong Kong was the EU's 20th largest trading partner in goods in 2018 and ranked as the EU's 8th trading partner in Asia. The EU is Hong Kong's second major trade partner after China.

Further, let us carry out an analysis of the share of the export operations of the Baltic countries to the countries of Southeast Asia (Figure 3).

From the presented diagram of Figure 2, it can be seen that Estonia's export operations to the countries of Southeast Asia in 2017 amounted to 3.38\%, 2.13\% in Latvia and $2.50 \%$ in Lithuania. It should be pointed out that Lithuania holds the first place in total export operations, with the country's exports amounted to $684.71 \mathrm{mln}$ USD, Estonia is in the second place

Table 2

Export-import operations of the Baltic countries and Southeast Asian countries in 2017, USD, developed by the author

\begin{tabular}{|l|c|c|c|c|c|c|}
\hline \multirow{2}{*}{ Country } & \multicolumn{2}{|c|}{ Estonia } & \multicolumn{2}{c|}{ Latvia } & \multicolumn{2}{c|}{ Lithuania } \\
\cline { 2 - 7 } & Import & Export & Import & Export & Import & Export \\
\hline PRC & $1.47 \mathrm{~B}$ & $248.47 \mathrm{M}$ & $439.89 \mathrm{M}$ & $42.63 \mathrm{M}$ & $929.4 \mathrm{M}$ & $203.01 \mathrm{M}$ \\
\hline Hong Kong & $6.77 \mathrm{M}$ & $26.16 \mathrm{M}$ & $15.82 \mathrm{M}$ & $29.9 \mathrm{M}$ & $18.55 \mathrm{M}$ & $38.44 \mathrm{M}$ \\
\hline Japan & $258.38 \mathrm{M}$ & $79.65 \mathrm{M}$ & $22.3 \mathrm{M}$ & $50.5 \mathrm{M}$ & $43.73 \mathrm{M}$ & $133.73 \mathrm{M}$ \\
\hline South Korea & - & $73.88 \mathrm{M}$ & $25.71 \mathrm{M}$ & $61.8 \mathrm{M}$ & $204.68 \mathrm{M}$ & $93.53 \mathrm{M}$ \\
\hline Singapore & $10.99 \mathrm{M}$ & $60.04 \mathrm{M}$ & $10.76 \mathrm{M}$ & $16.8 \mathrm{M}$ & $2.06 \mathrm{M}$ & $216.00 \mathrm{M}$ \\
\hline Taiwan & $96.394 \mathrm{M}$ & $23.524 \mathrm{M}$ & $83.47 \mathrm{M}$ & $5.2 \mathrm{M}$ & $119.816 \mathrm{M}$ & $22.437 \mathrm{M}$ \\
\hline Total & $\mathbf{1 4 5 4 6 . 1 7 M}$ & $\mathbf{1 4 4 2 8 . 9} \mathbf{M}$ & $\mathbf{1 5 8 3 2} \mathbf{M}$ & $\mathbf{1 1 6 4 7 M}$ & $\mathbf{3 2 3 2 8 . 1 M}$ & $\mathbf{2 7 3 3 0 . 0 M}$ \\
\hline
\end{tabular}

Source: Report of Trading Economics (Report of Trading Economics) 


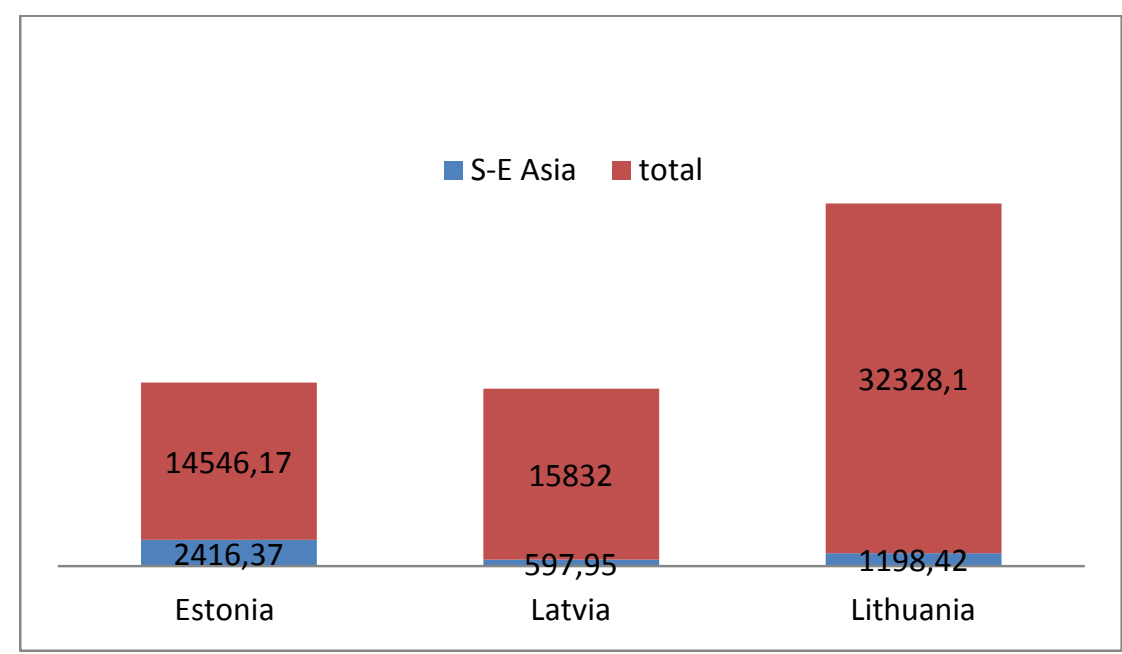

Figure 2. Import of Southeast Asian countries to the Baltic countries in 2017, mln USD, developed by the author

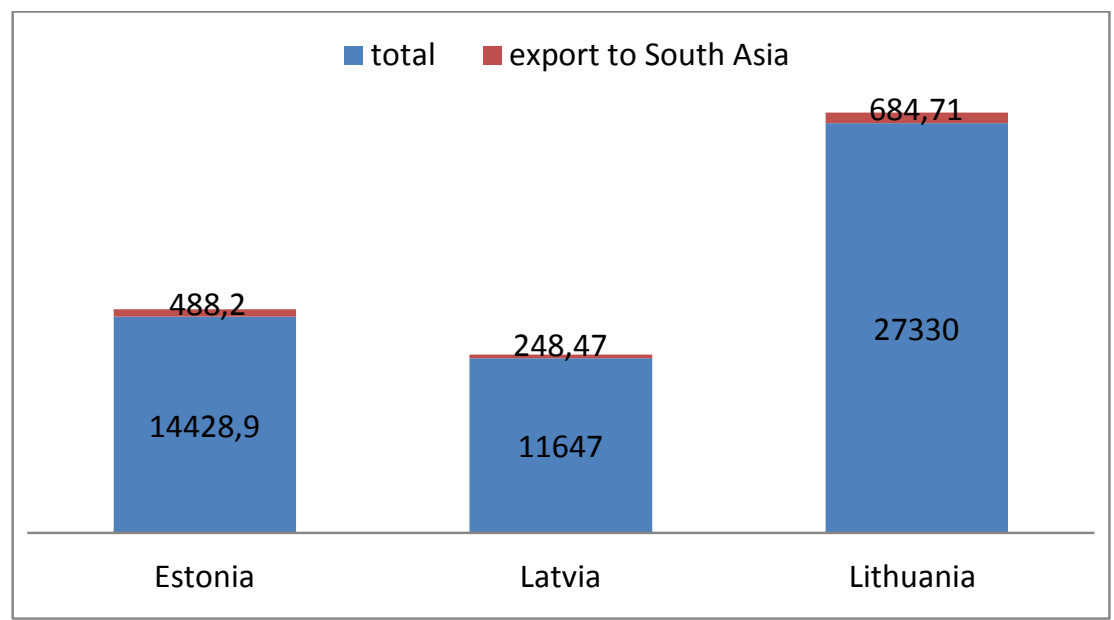

Figure 3. The volume of export of the Baltic countries to Southeast Asia in 2017, mln USD, developed by the author

with $488.2 \mathrm{mln}$ USD and Latvia is in the third place with $288.47 \mathrm{mln}$ USD, which is 2.7 times less than in Lithuania and 2 times less than in Estonia. The relevance of this research is determined by the low rates of Latvia's export operations.

As the author presented in table 1 and illustrated in Figure 1, the volume of imports of Southeast Asian countries exceeds the volume of exports of the Baltic countries, and this is the reason for the study of the growth potential of export operations of the Baltic countries.

Thus, in 2017 Estonia exported goods to the People's Republic of China in the amount of $248.47 \mathrm{mln}$ USD, in the second place is Japan with $79 \mathrm{mln}$ USD, $65 \mathrm{mln}$ USD and South Korea slightly inferior to Japan in 2017, where the export volume amounted to $73.88 \mathrm{mln}$ USD. Singapore with $60.04 \mathrm{mln}$ USD, a small share -26.16 mln USD exports to Hong Kong and $23.524 \mathrm{mln}$ USD to Taiwan.
Further, let us consider the level of imports of Estonia in Southeast Asia, Figure 4.

The main importer from Southeast Asia in Estonia is the People's Republic of China (China), the import volume of which is $1.47 \mathrm{bln}$ USD. It should be noted that China's share is $60.8 \%$ of the total volume of imports of Southeast Asian countries with the Baltic countries. The next important importing country in 2017 is Japan with $258.38 \mathrm{mln}$ USD and Taiwan with $96394 \mathrm{mln}$ USD is in the third place in the countries of importers of Southeast Asia.

The next Baltic country is Latvia, an analysis of Latvia's export-import operations with the countries of Southeast Asia (Figure 5).

As we can see from the diagram calculated by the author, Latvia's exports to the countries of Southeast Asia takes up insignificant volume. Thus, South Korea is the leader in Latvian exports from South Asia with a volume of transactions of $61.8 \mathrm{mln}$ USD, Japan ranks 


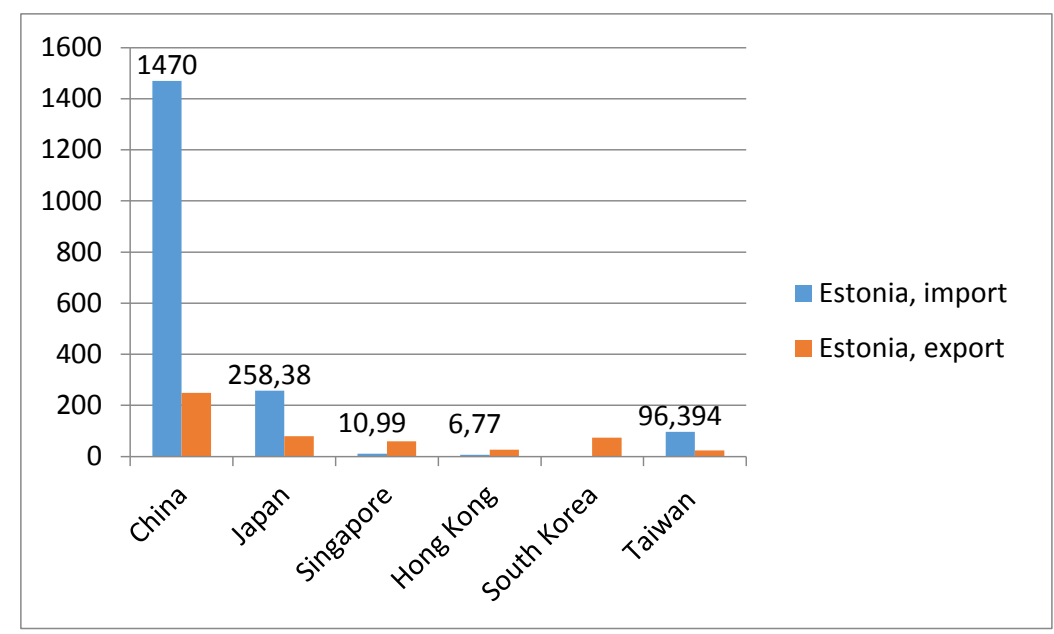

Figure 4. Export - import of Estonia into the countries of Southeast Asia in 2017, mln USD, calculated by the author

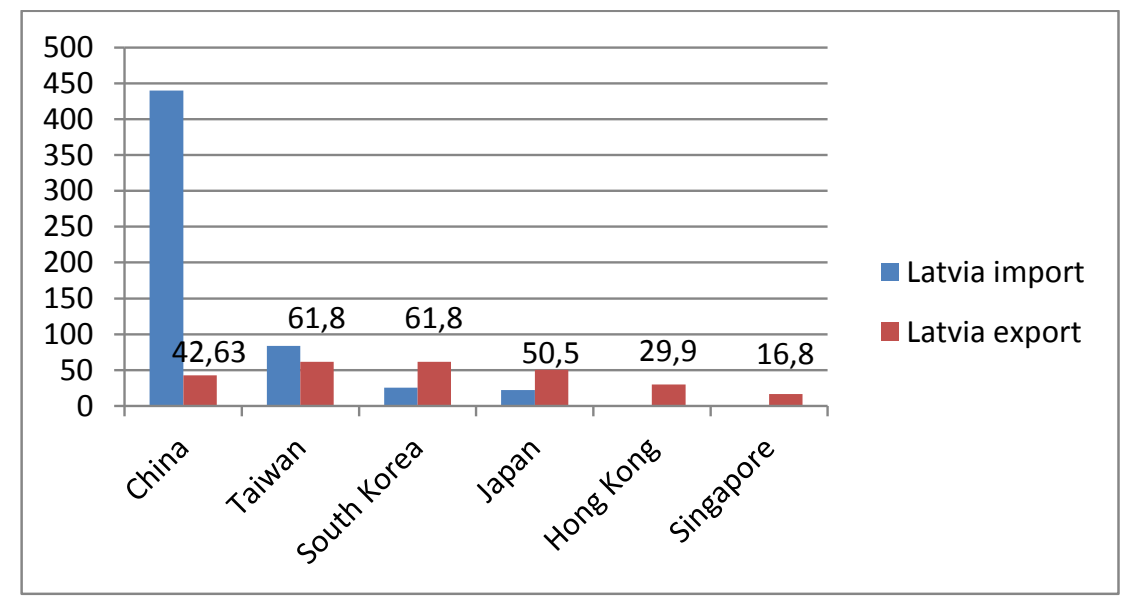

Figure 5. Latvia's export - imports to countries of Southeast Asia in 2017, mln USD, calculated by the author

second place with $50.5 \mathrm{mln}$ USD and China ranked the third place in 2017 with $42.6 \mathrm{mln}$ USD. An insignificant share belongs to Singapore and Taiwan with $16.8 \mathrm{mln}$ USD and $5.2 \mathrm{mln}$ USD respectively.

The diagram clearly demonstrates that the level of imports to Latvia of Asian countries significantly exceeds the level of exports. Thus, the leader among the examined states is China with $439.89 \mathrm{mln}$ USD, the second place belongs to Taiwan with $83.47 \mathrm{mln}$ USD, South Korea and Japan import goods to Latvia for 25.71 and $22.3 \mathrm{mln}$ USD, respectively, and the share of Hong Kong in Latvian imports in 2017 amounted to $15.82 \mathrm{mln}$ USD.

Thus, Lithuania is not an exception from the Baltic countries: import operations are the main operations with the countries of Southeast Asia. The leader in imports among the countries analyzed is PRC, the second place belongs to South Korea with $204.68 \mathrm{mln}$ USD and the third place to Taiwan with $119.816 \mathrm{mln}$ USD, a small share falls to Hong Kong with $18.55 \mathrm{mln}$ USD and Singapore with $2.06 \mathrm{mln}$ USD in 2017.
However, in Lithuania, export operations with Singapore, Japan and Hong Kong show a positive trade balance: Lithuania's exports to Singapore amounted to $216 \mathrm{mln}$ USD in 2017, which is almost 10 times more than imports in the research year, exports to Japan are 3 times more than imports and amounted to $133 \mathrm{mln}$ USD and exports to Hong Kong are 18 times more than imports and equal to $38.44 \mathrm{mln}$ USD. Lithuania's export operations in the PRC are 4 times less than imports and amounted to $203 \mathrm{mln}$ USD, while exports to South Korea are almost 2 times less than imports and amounted to $93.53 \mathrm{mln}$ USD in 2017. Lithuanian export operations to Taiwan are more than 5 times higher than imports from Taiwan and amounted to only $22.437 \mathrm{mln}$ USD.

It should also be noted that the growth of trade operations between countries leads to an increase in the number of tourists in the countries. It should be noted that there has been an increase in tourists from China, Japan and South Korea over the past 3 years from 2016 to 2018 , table 3 . 


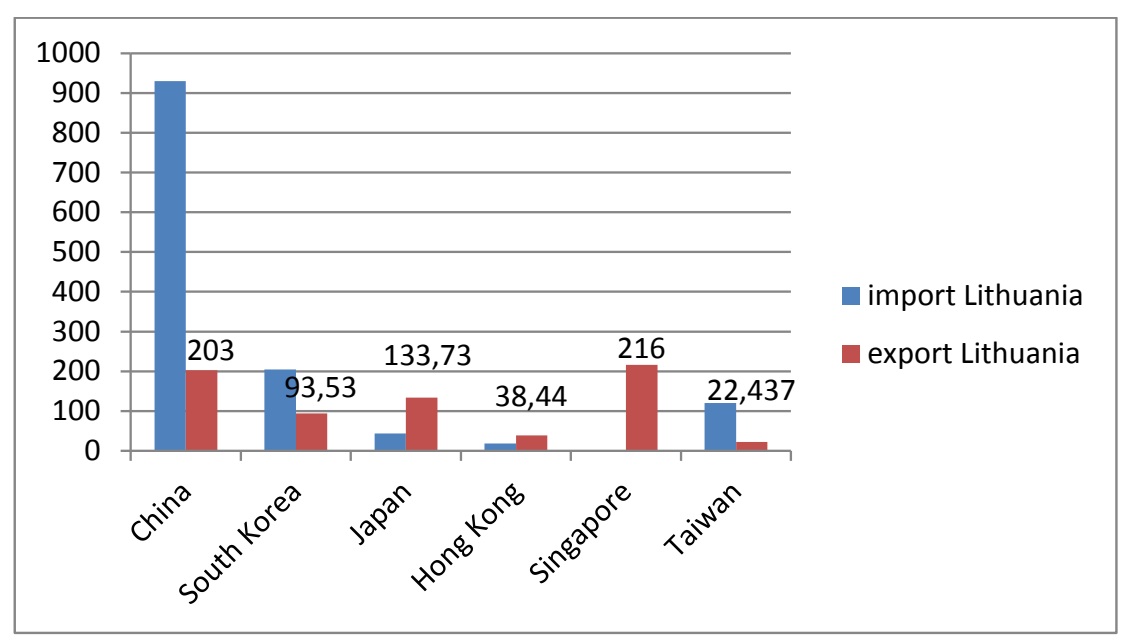

Figure 6. Export - import operations of the countries of South-East Asia and Lithuania in 2017, $\mathrm{mln}$ USD calculated by the author

Table 3

Dynamics of the number of tourists from Southeast Asia to Latvia from 2016 to 2018

\begin{tabular}{|l|c|c|c|}
\hline \multicolumn{1}{|c|}{ Country } & 2016 & 2017 & 2018 \\
\hline Japan & 23191 & 24576 & 29534 \\
\hline China & 20549 & 22724 & 22000 \\
\hline The Republic of Korea & 5296 & 7056 & 6953 \\
\hline
\end{tabular}

Source: developed by the author based on the Latvijas Centräläs statistikas pārvalde

As you can see from the data presented in table 3, the leaders among the countries of Southeast Asia in Latvia's inbound tourism are Japan with 29534 people in 2018, China is in second place with 22000 people and the third place belongs to the Republic of Korea with 6953 people in 2018. Undoubtedly, the increase in imports to Latvia also leads to an increase in the number of tourists to the country. However, an increase in Latvia's exports to the countries of Southeast Asia will increase the number of tourists from Latvia.

Further, we will carry out an analysis of the number of tourists to the other Baltic countries - Estonia and Lithuania (table 4).

Table 4

Dynamics of the number of tourists to Estonia from South-East Asia

\begin{tabular}{|l|c|c|c|}
\hline \multicolumn{1}{|c|}{ Country } & 2016 & 2017 & 2018 \\
\hline Japan & 23953 & 28831 & 31786 \\
\hline China & 14167 & 19698 & 20381 \\
\hline The Republic of Korea & 14024 & 16275 & 14997 \\
\hline
\end{tabular}

Source: developed by the author based on the Statistics Estonia

The data in table 4 show that the maximum number of tourists to Estonia from Japan is 23953 people in 2016, 28831 people in 2017 and 31786 people in 2018, although Japan ranks the second place among the countries of Southeast Asia in terms of imports to
Estonia. As indicated by the author above, the leader in terms of exports and imports to Estonia is China, but the Chinese are second to inbound tourists to Estonia. Thus, the dynamics of tourists from China: 20381 people in 2018, 19698 people in 2017 and 14167 people in 2016, almost 30\% less than tourists form Japan. South Korea ranks third in the volume of trade operations with Estonia, among South countries of East Asia, tourists from South Korea are also in third place.

Thus, the carried out analysis of the export-import operations of the Baltic countries to the countries of South-East Asia has shown that the Baltic countries have the potential for growth in export operations. According to the author, the volumes of export indicated that the import operations of the Baltic countries are of interest to small and medium-sized businesses what the economy of the EU countries, including the Baltic States, is based on.

In the Baltic countries, the following quantitative criteria exist for clasifying enterprises as small businesses: in Latvia, the enterprises, where the number of employees does not exceed 25 people, a turnover is not more than $40 \mathrm{mln}$ EUR, a book value of fixed assets is no more than $27 \mathrm{mln}$ EUR; in Lithuania, the enterprises with the number of employees no more than 250 people and a turnover of no more than $40 \mathrm{mln}$ EUR; in Estonia, the enterprises with the number of employees no more than 80 people with a turnover of no more than $40 \mathrm{mln}$ EUR.

The procedure for registering a small business in Latvia is 1 business day, in Lithuania is 2 business days, in Estonia is 13.5 hours. The average registration fee for a start-up entrepreneur in Estonia is 183 EUR. There is an additional charge (190 EUR) for expedited service. In Latvia, expedited services are services for registration of changes, registration of branches, liquidation of a company. According to a study of the International Business Registers Report (2018), 
entrepreneurs of the Baltic countries noted that the use of artificial intelligence technologies in the form of chat bot positively affected the quality and speed of the small business registration process (International Business Registers Report 2018).

\section{Conclusions}

Thus, the fulfillment of the set goals of sustainable development, enshrined in the UN program "Transformation of our world: The 2030 Agenda for Sustainable Development" is possible to increase trade operations between regions. The analysis carried out by the author of trade operations between the Baltic countries and Southeast Asia showed that the main partners are PRC, Hong Kong, Taiwan, Singapore, Japan and South Korea. The volume of imports from the countries mentioned to the Baltic countries significantly exceeds the volume of exports and, according to the author's opinion, this is a potential for growth in exports of the Baltic countries. The analysis has shown that PRC is the leader in exports and imports to the Baltic countries, in Estonia; the second place belongs to Japan and third to South Korea in terms of export volume. In Latvia, Taiwan ranks second in terms of export volume, South Korea is the third strategic partner, but in Lithuania the second place in export operations to countries in Southeast Asia belongs to Singapore and the third place belongs to Japan.

It should be noted that the presented three countries of the PRC, Japan and South Korea are the leaders in the tourism industry of the Baltic countries. However, the championship belongs to Japanese tourists in all the Baltic countries, tourists from China are in second place and tourists from South Korea are in the third place. Thus, the carried out research allowed identifying the growth potential of export operations of the Baltic countries to the region of South-East Asia that will lead to an increase in the turnover of the tourism industry of trading states, including. The research has shown that the expansion of trade relations between the Baltic countries and Southeast Asia is possible through the creation of joint ventures of SMEs, the formation of which in the Baltic countries is estimated by international experts to be very short in time and not costly.

\section{References:}

Charles, P. (1986). Kindleberger The World in Depression, 1929-1939 the History of the World Economy in the Twentieth Century Series, University of California Press.

Chien-peng Chung (2013). China and Japan in "ASEAN Plus" Multilateral Arrangements: Raining on the Other Guy's Parade, Asian Survey. Vol. 53, pp. 801-824. doi: 10.1525/as.2013.53.5.801

EU and China agree on scope of the future investment deal, Brussels, 15 January 2016. Retrieved from: https://trade.ec.europa.eu/doclib/press/index.cfm?id=1435

Alice Landau (2004). The International Trade System. Routledge. New York.

Nguyen Huua, Deniz Dilan Karaman Örsal (2019). A new and benign hegemon on the hoizon? The Chinese century and growth in the Global South Economics. Retrieved from: http://www.economics-ejournal.org/ economics/discussionpapers/2019-60

Nori Katagiri (2015). Strategy and Grand Strategy for the Future of Asia, Asian Survey. Vol. 55, No. 6 (November/ December), pp. 1170-1192, University ofCalifornia Press. Retrieved from: https://www.jstor.org/stable/26364331 Paul Krugman (1996). Pop Internationalism. New York.

L. Lancaster (1991). The Bowyer Ledgers Hardcover, Oxford University Press.

Lancaster, Kelvin J. (1966). "A New Approach to Consumer Theory" (PDF). Journal of Political Economy. Vol. 74(2), pp. 132-157. doi: 10.1086/259131.JSTOR

Robert C. Feenstra (2004). Advanced International Trade Theory and Evidence Publisher: Princeton University Press. Princeton, NJ.

Rybczynski, T. M. (1955). "Factor Endowment and Relative Commodity Prices". Economica. Vol. 22(88), pp. 336-341. doi: 10.2307/2551188

Seung-Youn Oh (2015). How China Outsmarts WTO Rulings in the Wind Industry, Asian Survey, Vol. 55, No. 6 (November/December), pp. 1116-1145.

Stolper, W. F., Samuelson, \& Paul, A. (November 1941). Protection and real wages. The Review of Economic Studies. Vol. 9(1), pp. 58-73. doi: 10.2307/2967638. JSTOR

Samuelson (2009). Economics McGraw-Hill Education; Edition: 19th. doi: https://doi.org/10.1057

Wassily, W. (1978). Leontief Essays in Economics: Theories, Facts and Policies, v. 2, Taylor \& Francis Inc.

United Nations, Transforming our world: the 2030 Agenda for Sustainable Development, Resolution adopted by the General Assembly on 25 September 2015. Retrieved from: https://www.un.org/en/development/desa/ population/migration/generalassembly/docs/globalcompact/A_RES_70_1_E.pdf

The Statistics Estonia. Retrieved from: https://www.stat.ee/en

Central Statistical Bureau of Latvia. Retrieved from: www.csb.gov.lv

The Lithuanian Department of Statistics. Retrieved from: https://www.stat.gov.lt/en

EUROSTAT. Retrieved from: www.eurostat.eu 